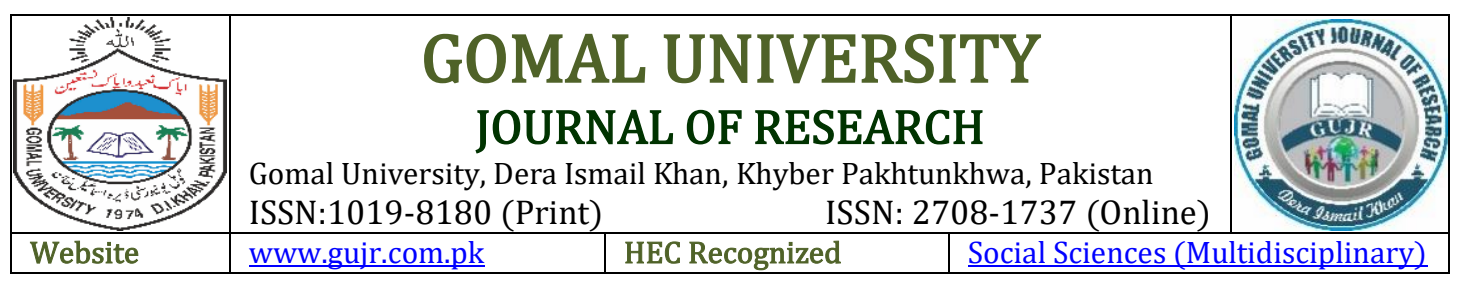

\title{
THE RELATIONSHIP OF ORgANIZATIONAL CYNICISM WITH THE JOB SATISFACTION: THE MEDIATING ROLE OF PSYCHOLOGICAL CONTRACT BREACH
}

\author{
Aneela Sheikh ${ }^{1}$, Abdul Khaliq Alvi², Khalil Ur Rehman ${ }^{3}$ \\ ${ }^{1}$ School of Educational Studies, Universiti Sains Malaysia (USM), Penang, MALAYSIA \\ ${ }^{2}$ Department of Management Sciences, Lahore Garrison University, Lahore, Pakistan \\ ${ }^{3}$ Department of Business Administration, Lahore Leads University, Lahore, Pakistan
}

\begin{tabular}{|c|c|}
\hline $\mathrm{AR}$ & BSTRACT \\
\hline $\begin{array}{l}\text { Key } \\
\text { Psycl } \\
\text { Brea } \\
\text { Cyni } \\
\text { Satis } \\
\text { Pakis }\end{array}$ & \multirow{2}{*}{$\begin{array}{l}\text { This research inspects the relation of psychological contract breach, } \\
\text { organizational cynicism and job satisfaction. This is correctional } \\
\text { research and date is collected from } 274 \text { nurses randomly from public } \\
\text { sector hospitals of Lahore Pakistan. Result described that all three } \\
\text { hypotheses for direct relationships of psychological contract breach } \\
\text { and the organizational cynicism with the job satisfaction and for the } \\
\text { relationship of organizational cynicism with psychological contract } \\
\text { breach are accepted. Moreover, psychological contract breach partially } \\
\text { mediates the relation of +other sectors like the banks, telecom and } \\
\text { education sector for validate the results. It is also worthwhile to collect } \\
\text { the data from nurses of private sectors where they face lot of hardships } \\
\text { and the results of nurses of Govt. and private sector. For generalizing } \\
\text { the results data will also collect cities like Islamabad, Faisalabad and } \\
\text { Karachi. } \\
\text { (9) @ \& } 9020 \text { Gomal University Journal of Research }\end{array}$} \\
\hline $\begin{array}{l}\text { istory: } \\
\text { bmission: } \\
20 \\
\text { ceptance: }\end{array}$ & \\
\hline orresponding Autho & \\
\hline & \\
\hline
\end{tabular}

\section{INTRODUCTION}

Current research is designed to check mediation role of psychological contract breach between the relationship of organizational cynicism and job satisfaction. The variable of interest in this research is job satisfaction. Job satisfaction is being emerged within the organization when an individual makes an assessment about the social problems, other related internal and external issues about the job. High level of job satisfaction among the employees may boost the level of production, morale and such feeling of accomplishment which ultimately decrease the employee intention to exit and to decrease searching of job (Spector, 1997; Aziri, 2011; Rahman, Akhter \& Khan, 2017). However, the decreased level of job satisfaction may result in high absent ratio and high rate of job exit (Kwok, Cheng \& Wong, 2015; Peiró, Kozusznik, Molina \& Tordera, 2019). It 
is also linked with delight and happiness in life due to the recognition and enforcement of effectiveness and the success of organization (Kwok et al., 2015; Ayala, Silla, Tordera, Lorente, \& Yeves, 2017). It also plays vital role in the life satisfaction (Askitas, Zimmermann, Guzi \& García, 2015; Sirovátka, Guzi \& Saxonberg, 2019). That's why, it very crucial to understand the different techniques and parameters to improve the job satisfaction at work place (Kwok et al., 2015).

According the Mardanov, Heischmidt and Henson (2008) and DeConinck (2009) about 77\% employees in USA are found to be dissatisfied from their jobs and the study also disclosed that dissatisfaction is one of the major issues behind high turnover rate of the employees. It is being identified that mostly employees seem dissatisfied in early job time and ratio of dissatisfaction ranges about $26.1 \%$ - $45.9 \%$ within the first year of their job particularly in the European Nations (Auer \& Cazes, 2000). Still, that dissatisfaction ratio is increased in USA to $65.9 \%$ (Erlinghagen, 2019). There was research conducted in Turkey on 1293 sample size of employees from different departments and professions and concluded that about $41.7 \%$ employees are dissatisfied from their jobs and even lives (Yesilyaprak \& Boysan, 2015; Anene, 2019). According to findings of Chou, Hecker and Martin (2012) employees prefer to work for longer working hours in China and Hong Kong in comparison to west side of the world. Hong Kong is among the top 5 from the 72 nations where working hours longer like employees work about 2296 hours in one year (Pisani, Sapir, Véron \& Wolff, 2012). This bad situation is present in Asian countries (Chandra, 2012; Yang \& Islam, 2020) and evident in the countries like America, Latin America and East Asia.

Although, it is the most considerable factor in the countries like Hong Kong and China, where the lower side of job satisfaction also has reverse effect on physical and personal level well-being (Kwok et al., 2015; Leung, Cheung \& Liu, 2011; Dahiya, \& Rangnekar, 2020). In addition to that, different researchers also have identified that there is high job dissatisfaction among the lowlevel wages people, the young marginal type workers and other part time workers (Ananiadou, Henry, Evans \& Wolf, 2004; Brown, Taylor, McKenzie \& Perkins, 2015). Above discussion clearly describe that job satisfaction is main concern for the organizations of modern age. To solve this problem current research designed to examine the effect of organizational cynicism and psychological contract breach on job satisfaction and also mediating role of psychological contract breach for the relation of organizational cynicism with job satisfaction. Kuang (2013) examines that psychological contract breach has positive significant influence on organizational cynicism. This result is also validated by the other researchers (Bashir \& Nasir 2013; Li \& Chen 2018). Similarly, different studies recommend that psychological contract breach has negative significant influence on the job satisfaction (Ballou, 2013; Rayton, \& Yalabik 2014; Marselou, 2017).

Organizational cynicism has negative significant effect on job satisfaction (Abouel, 2011; Volpe, Mohammed, Hopkins, Shapiro \& Dellasega, 2014; Grama, 2017). Basically, the organizational cynicism is personal negative thinking like the distress, dissatisfaction and desperation about the management and organization (Özler \& Atalay, 2011; Karakaya, 2019). It is the result of the employees trusting on organization that they do lack of honesty. Especially morality boosting, justice within organization and honesty being manipulated. With passage of time, researchers are more diverted towards the organizational cynicism. Cynicism is described as the employee's negative emotions like the anger, desperation and dissatisfaction. Due to that, there are number 
of issues generated (Özler \& Atalay, 2011). Old studies consider the contract breach as a separate event like employees think that their wages are not increased as promised, although in recent studies it was suggested psychological contracts should be considered and treated as dynamic procedures (Bankins, 2015; Solinger, Hofmans, Bal \& Jansen, 2016; Jacobs, Kreutzer \& Vaara, 2020).

Parallel with concept of breach as a step-by-step process, it can analyze in detail as neuroscience efforts to recognize the intrapersonal procedures those reacts against the thought of breach (Wiechers, Shapiro, Lub, Have, 2018). Researchers also suggested that it is a psychological state which helps for quick understanding to respond a change from automatic procedure to fully sensed attention to the psychological like contract. All the actions can in direct or indirect way, even slowly "the procrastination of the organization in meeting its obligations" and designed by personal level work environment and such characteristics. Enforcement is basically the distress among the individual's psychological contract to shake the thoughts of that person. There are multidimensional aspects about the employees enforce to have psychological contract that is related with different other organizational and individual factors and there can subsequent the emergence of different attitude, reactions, behaviors and consequential parameters with respect to the responsibility of the psychological contract breaches (Conway, Kiefer, Hartley \& Briner, 2014).

\section{LITERATURE REVIEW}

In previous researches the relationship of organizational cynicism and psychological contract breach with job satisfaction and relationship of the organizational cynicism with psychological contract breach tested at individual level. This research add in the body of research by proposes the psychological contract breach, organizational cynicism and job satisfaction in single model. From the best of researcher knowledge, this is the initial effort to check the mediating effect of organizational cynicism for the relation of psychological contract breach with job satisfaction. This research is also initial effort to check the propose model in nurses of Pakistan via existing research.

\section{Job Satisfaction}

Job satisfaction is the inner emotions about the job and its different dimensions. It really deals with how an individual feel about the work (Rahim, 1982; Danganan, Velasquez, Guinto \& Mac, 2019). It is favoring tendency to judge his or her work (Stewart, 1983). Basically, job satisfaction is the qualitative measurement of liking and disliking job work (Spector, 1997). It suggests the good feelings of the employees related to their job. It describes overall assessment of work and all related dimensions by the employee (Muhidin, 2019). Job satisfaction is happiness collected through work assessment to analyze the job importance (Middermann, Kratzer \& Perner, 2020). It is basically the inner thought and the belief about the job (Price, 2001; Ababneh, \& Hackett, 2019). It shows the tendency of an individual level of satisfaction with respect to his or her inside and outside aspects from the job (Bhuian \& Menguc, 2002; Obodo, Okonkwo \& Aboh, 2019). It is being judged and analyzed as per the individual's feelings related to the job work and its relevant aspects (Obodo, et al., 2019). It shows the reflection on the base of their personal needs, desires and certain expectations about the job. Such indicators are very much considered by the employees during job satisfaction (Sempane, Rieger, Roodt, 2002; Wen, Muthuveloo \& Ping, 2018). 
It is also a seeming response to the job as an individual to perceive certain things from the job and when compare it with reality (Rothman \& Coetzer, 2002; Ayalew, 2019). Job satisfaction is the inside delight from the job and to enjoy the work and feel of proud on excellent performance of work (Mayorga, 2019). It is the highly interesting thing for the employees within organization and individuals who are studying that. It is one of important factors in study of organizational behavior and for the theory of organizational based experience which is ranged from the job development to even supervision (Lashari, Shah, Malkawy \& Parveen, 2019). It is based about job including employee expectations from the job (Hussami, 2008; Wong, Norzi, Chan \& Jaafar, et al., 2020). The right analysis of job may be helpful to understand importance of an employee and the reasons to be motivated (Yang, Ge, Hu, Chi \& Wang, 2009). Even in current advanced era particularly in field of organizational psychology (Kwok et al., 2015). It does provide physical outcome as approach is effectively utilized (Ahmed, Andersson \& Hammarstedt, 2013). Studies are being conducted to understand factors behind job satisfaction (Memduhoğlu \& Altunova, 2020). Within the social setup it is not easy way to understand factors behind job satisfaction. Researchers argued that job satisfaction is very wide concept which contain different other vital factors/issues as well (Ayala et al., 2017; Judge \& Mueller, 2012; Gong, Wu, Huang, Yan \& Luo, 2020).

\section{Psychological Contract Breach}

The concept of employee psychological engagements may consist on ideological remunerations clearly ignored although it is tried to understand the employees output with the help of research to know the impact of psychological contract. Thompson \& Bunderson (2003) ideological state is the (credible commitment to pursuing a valued cause or principle (not limited to self-interest) that are implicitly exchanged at the nexus of the individual-organization relationship). As the result employees who trust in ideological part to the psychological engagement hold the trust that organization gives the situation to the employees to become part straight away or indirect way. Previous studies consider the contract breach as a separate event like employees think that their wages are not increased as promised, although in recent era researchers have suggested that psychological contracts should be considered and treated as dynamic procedures (Bankins, 2015; Solinger et al., 2016; Jacobs, et al., 2020). Parallel with the concept of breach as a stepby-step process, it can analyze in the detail as neuroscience efforts to know the intrapersonal procedures those reacts against the thought of breach (Wiechers et al., 2018). Researchers also suggested that it is the psychological state which helps for quick understanding the vents and to respond a change from automatic procedure to fully sensed attention to the psychological like contract.

All the actions can in direct or indirect way, even slowly "the procrastination of the organization in meeting its obligations" and designed by the personal level work environment and such that characteristics. Enforcement is basically the distress among the person's psychological contract to shake the thoughts of that person. There are multidimensional aspects about the employees enforce to have psychological contract with different other organizational factors and there can subsequent emergence of different reactions and behaviors with respect to the responsibility of psychological contract breaches (Conway et al., 2014). As per the empirical conclusion contract breach may be a subsequent situation for working partner relations with outcome of increased in deviance and rude attitudes among the coworkers (Bordia, Restubog, Bordia \& Tang, 2010; Deng, Shapiro \& Yang, 2018). Kuang (2013) examines that Psychological Contract Breach has positive significant influence on the organizational cynicism. This result is also validated by the 
other researchers (Bashir \& Nasir 2013; Li \& Chen, 2018). Similarly, the psychological contract breach has negative significant influence on job satisfaction (Ballou, 2013). This result is also validated by the other researchers by examining the issues (Rayton \& Yalabik 2014; Marselou, 2017).

\section{Organizational Cynicism}

Organizational cynicism is an internal thought which makes an individual unfriendly towards the organization as per his or her believe organizations are dishonest and will make fool of their employees (Nair \& Kamalanabhan, 2010; Putranta, 2020). Basically, it is the personal negative thinking like distress, dissatisfaction and desperation about the management and organization (Özler et al., 2011; Karakaya, 2019). It is the result of employees trusting on organization that they do lack of honesty. Especially morality boosting, justice within organization and honesty are being manipulated. With passage of time, researchers are diverted toward organizational cynicism. The term of cynicism has captured high intention with respect to different contents within social sciences such as sociology, political science, religion, philosophy and psychology (Ince \& Turan, 2011; Atikbay, \& Öner, 2020). Cynicism is described as the employee's negative emotions like the anger, desperation and dissatisfaction. Due to that, there are number of issues generated for the entire management and organizations (Özler et al., 2011). According to other researcher's cynicism is basically a personality characteristic or a behavior instead of a lifestyle (Özgener et al., 2011). Particularly in the America, it is being considered as the norm in different organizations and same situations in the Egypt and the different other countries in the world as well.

Different researchers suggested that there is a direct impact to decrease level of job satisfaction particularly in the last 10 years. There is a survey concluded that about $49 \%$ of Americans are founded satisfied from their jobs which is decreased from $58 \%$ within last 10 years (Akhigbe, \& Gail, 2017). As the level of job satisfaction going down and there will be high organizational cynicism that will ultimately create a bad situation for the management to control over such changed scenario. It can be described as overall and behavior of discouragement, distress, anger, mistrusting situation, wrong ideology and other social type skills (Andersson, 1996). It becomes the realistic point of thought when any organization moves towards dishonesty in the result that may hit hard to goodwill and crucial attitudes when it reacts in combination with very negative type emotions (Abraham, 2000; Mousa, \& Abdelgaffar, 2017). It can be perfectly analyzed as per the high working experience of the analyst (Mousa, \& Abdelgaffar, 2017). It is the kind of un-satisfaction from organization. This is the hard point of the view with honesty, fair actions, decreased moral and lower level of sincerity within organization (Bernerth, Armenakis, Feild \& Walker, 2007; Gkorezis, Georgiou \& Theodorou, 2018). It is also called the behavior emerged with the level of faith, inner thinking and working actions in concerned organization with more diligence.

Basically, it is the reverse behavior included three aspects think by individual about organization like cognitive, behavioral and affective structure of the organizational cynicism (Stanley, Meyer \& Topolnytsky, 2005; Gigliotti, Marshall \& Gonzalez, 2019). The first cognitive aspect of the cynicism is related to the faith in organization that it lacks in honesty. Also, it is the faith about organization lacks in justice system, level of sincerity and down honesty. Individuals trust that such practices are normally changed. Those are changed with certain wrong practices and the immoral behaviors as considered as the organizational norms. Similarly, they also believe in 
that the human resources are not trustable and even inappropriate in their behavioral actions. Second, the affective aspect of cynicism is based on inner emotions and sentiment response towards organization. It is the high emotion base response to the organization. The individuals also feel un-honored and harsh about the organizations and even feel disturbance, hate and shame when they thought about the organizations. That's why it is linked with different negative thoughts. Third, the behavioral aspect of organizational cynicism describes the negative actions and disrespecting behaviors. This aspect is based on the negative and constant wrong behaviors. Hard thinking about organization is highlighted action-based issues. Those can be happening in different ways such hard emotions about organization like lack sincerity and honesty within organization. Organizational cynicism has negative significant influence on job satisfaction (Abouel, 2011). This result is also validated by the other researchers (Volpe et al., 2014; Grama, 2017).

\section{Hypothesized Research Model}

\section{Theoretical Framework}

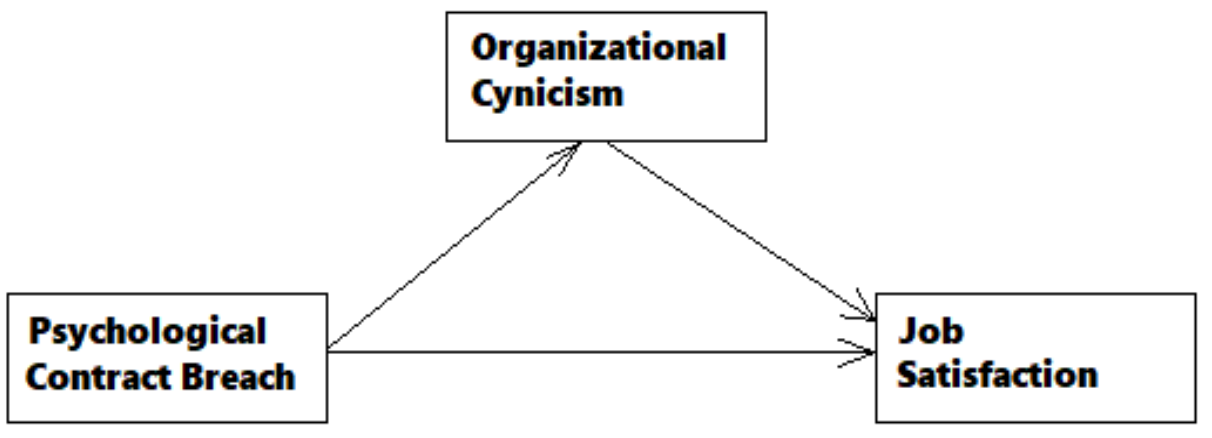

\section{Theoretical Background}

According to Abraham, (2000), discrepancy theory provides theoretical basis for the research and described that the psychological contract breach has negative significant impact on the job satisfaction and positive relationship with organizational cynicism as per evidence from existing studies.

\section{Research Hypothesis}

H1: Psychological contract breach has negative significant relationship with job satisfaction H2: Psychological contract breach has positive significant link with organizational cynicism $\mathrm{H}_{3}$ : Organizational cynicism has negative significant relationship with job satisfaction $\mathrm{H}_{4}$ : Organizational cynicism play mediating role between PCB and job satisfaction

\section{RESEARCH METHODOLOGY}

\section{Target Population, Sample \& Sampling Technique}

Target population of current studies is consisted of nurses of public sectors hospitals of Lahore Pakistan. For this purpose, we select Services, Mao Hospital and Sheikh Zaid Hospital Lahore 
Pakistan. A sample of 274 nurses was drawn randomly for collecting the data. Total number of distributed questionnaires were 335. Returned questionnaires were 292 and uncompleted were 18 which were excluded from the final analysis. The data was analyzed with the help of the SPSS 24.

\section{Research Design and Type of Research}

This is cross-sectional research as data is collected from the respondents at the single time point and this research is the quantitative one as the relationship are based on the cause-and-effect relationship.

\section{Scale and Measurements}

The employee job Satisfaction is mesured with 6 item scale of Homburg \& Stock (2005) and reliability of that scale was $79.5 \%$. Organizational cynicism is measured with ten statements scale of Brandes, Dharwadkar \& Dean (1999) and reliability of scale was 86.5 \%. Psychological contract breach is mesured with 9 item scale of Robinson, \& Morrison, (2000) and reliability of that scale was $82.4 \%$ which have also been validated by different researchers. This research uses the five-point Likert type for calculating the response from strongly disagree to strongly agree.

\section{Reliability Analysis}

\section{Table 1}

Reliability Statistics

\begin{tabular}{lc}
\hline \multicolumn{1}{c}{ Variable's Name } & Alpha of Reliability \\
\hline Employee job Satisfaction & 0.85 \\
Organizational cynicism & 0.87 \\
Psychological Contract Breach & 0.79 \\
\hline
\end{tabular}

Table 1 indicates that all values of Cronbach's Alpha of the research variables which indicate the values are more than the threshold values (.060) and thus all the collected data is accurate and reliable.

\section{Correlation Analysis}

\section{Table 2}

Correlation Analysis

\begin{tabular}{lccccc}
\hline & $\begin{array}{c}\text { Mean } \\
\text { Value }\end{array}$ & $\begin{array}{c}\text { Standard } \\
\text { Deviation }\end{array}$ & $\begin{array}{l}\text { Employee } \\
\text { Satisfaction }\end{array}$ & $\begin{array}{l}\text { Organizational } \\
\text { Cynicism }\end{array}$ & $\begin{array}{l}\text { Psychological } \\
\text { Contract Breach }\end{array}$ \\
\hline $\begin{array}{l}\text { Employee } \\
\text { Satisfaction }\end{array}$ & 3.45 & 0.49 & 1 & & \\
$\begin{array}{l}\text { Organizational } \\
\text { Cynicism }\end{array}$ & 2.44 & 0.64 & $-0.47^{* *}$ & 1 & 1 \\
$\begin{array}{l}\text { Psychological } \\
\text { Contract Breach }\end{array}$ & 2.16 & 0.53 & $-0.34^{* *}$ & $0.53^{* *}$ & \\
** Correlation is significant at the 0.01 level (2-tailed) & & \\
\hline
\end{tabular}


Table 2 provides the values of mean, standard deviation and nature of correlation i.e., either it is positive or negative. The organizational cynicism is negatively correlated with employee job satisfaction and its value of " $\mathrm{r}$ " is $-0.47^{* *}$. Psychological Contract Breach is negatively correlated with employee job satisfaction and its value of " $\mathrm{r}$ " is $-0.34^{* *}$. The psychological contract breach is positively correlated with organizational cynicism and its value of " $\mathrm{r}$ " is $0.53^{* *}$, and confirmed association.

\section{Regression Analysis}

\section{Table 3}

\section{Regression Analysis}

\begin{tabular}{lccccc}
\hline & $\beta$ & SE & F & $\mathrm{R}^{2}$ & Decision \\
\hline $\begin{array}{l}\text { Path c (Step-1) } \\
\text { Outcome: Job Satisfaction }\end{array}$ & & & & & \\
$\begin{array}{l}\text { Predictor: Psychological Contract Breach } \\
\text { Step-2 (Path-a) }\end{array}$ & -0.34 & .075 & 60.74 & 0.27 & $0.000<0.01$ \\
$\begin{array}{l}\text { Outcome: Organizational Cynicism } \\
\text { Predictor: Psychological Contract Breach }\end{array}$ & 0.51 & 0.078 & 174.43 & 0.35 & $0.000<0.01$ \\
$\begin{array}{l}\text { Step-3 A (Path-b) \& Step-3 B (Path-c') } \\
\text { Outcome: JS, Predictor: OC }\end{array}$ & -0.46 & 0.073 & 124.75 & 0.29 & $0.000<0.01$ \\
Mediator: Organizational Cynicism & -0.19 & 0.088 & & & $0.014<0.10$ \\
Predictor: Psychological Contract Breach & -0.25 & 0.075 & & & $0.000<0.01$ \\
\hline P<0.01, P<0.05, P<0.10 & & & & &
\end{tabular}

Table 3 provides the values of regression analysis. For the relationship of psychological contract breach with job satisfaction, Value of $F$ is 60.74 and $R 2=0.27$ and Value of $\beta=-0.34$. value of $\mathrm{p}<0.01$, So hypothesis no 1about this relationship is accepted. This result is similar with results of previous researches (Ballou, 2013; Rayton, \& Yalabik 2014; Marselou, 2017). As the value of $\beta$ of this research is very close to results of above-mentioned researchers. For the relationship of psychological contract breach with organizational cynicism, Value of $\mathrm{F}$ is 60.74 and R2 $=0.35$ and Value of $\beta=0.51$. value of $\mathrm{p}<0.01$, So hypothesis 2 about this relationship is accepted. This result is similar with the results of previous researches (Kuang, 2013; Bashir \& Nasir 2013; Li $\&$ Chen 2018). As the value of $\beta$ of this research is very close to results of above-mentioned researchers. For relationship of organizational cynicism with satisfaction, Value of $\mathrm{F}$ is 124.75 and $\mathrm{R} 2=0.29$ and Value of $\beta=-0.46$. value of $\mathrm{p}<0.01$, So hypothesis 3 about this relationship is accepted.

This result is similar with the results of previous researches (Abouel, 2011; Volpe et al., 2014; Grama, 2017). As the value of $\beta$ of this research is very close to the results of above-mentioned researchers. For checking the mediation influence of organizational cynicism for the relation of psychological contract breach with job satisfaction. Current research analyses the three direct relationships. Table 3 describes that all these relationships are significant. For evaluating the mediation effect, current research regresses the independent variable (psychological contract breach) with mediator variable (organizational cynicism) on job satisfaction. It is observed that Value of $\beta$ is reduces from -0.34 to -0.25 . This value describes that mediation is exist for the relation of psychological contract breach with job satisfaction, but this is partial mediation. This 
is finding of the current research. This result is also logically justified as if we decrease the level of organizational cynicism by decreasing the level of the psychological contract breach that will reduce the strength of the direct relationship of the psychological contract breach with the job satisfaction.

\section{CONCLUSION}

There are many organizations whose employees are satisfied with their jobs. This may create problem in term of their productivity and affiliation of their jobs. Current research is based on nurses of government hospitals of Lahore. The current research was based upon four proposed hypotheses. Consequently, three of the hypotheses are about direct relationships and one is about the mediation effect of organizational cynicism for the for the relation of psychological contract breach with job satisfaction. All the hypotheses are accepted from results of correlation and regression to examine association and cause-\&-effect relationships. Also, organizational cynicism partially mediates the relation of psychological contract breach with job satisfaction. In future, these types of studies may also conduct on other sectors like banks, telecom and education sector for validate the results. It is worthwhile to collect data from nurses of private sectors where they face lot of hardships and the results of nurses of government and private sector. For generalizing the results data will also collect cities like Islamabad, Faisalabad and Karachi.

\section{REFERENCES}

Ababneh, K. I., \& Hackett, R. D. (2019). The direct and indirect impacts of job characteristics on faculty organizational citizenship behavior in the United Arab Emirates (UAE). Higher Education, 77(1), 19-36.

Abouel, G. M. B. E. (2011). The Impact of Organization Cynicism on Organization Commitment and Job Satisfaction, 1-20.

Abraham, R. (2000). Organizational cynicism: Bases and consequences. Genetic, social, and general psychology monographs, 126(3), 269.

Ahmed A, Andersson L, Hammarstedt M (2013) Sexual orientation and full-time monthly earnings, by public and private sector: evidence from Swedish register data. Review of Economic Household, 11(1):83-108

Akhigbe, O. J., \& Gail, O. J. (2017). Job Burnout and Organizational Cynicism Among Employees in Nigerian Banks. European Scientific Journal, 13(22), 125-140.

Ananiadou, K., Henry, R., Evans, K., \& Wolf, A. (2004). Identifying effective workplace basic skills strategies for enhancing employee productivity and development: scoping and pilot study report. National Research and Development Centre for adult literacy and numeracy, Institute of Education, University of London.

Andersson, L. M. (1996). Employee cynicism: An examination using a contract violation framework. Human relations, 49(11), 1395-1418.

Anene, J. O. (2019). The Impact of Non-counseling Duties on Burnout: A Single Case Study of Professional School Counselors (Doctoral dissertation, Grand Canyon University).

Askitas, N., Zimmermann, K. F., Guzi, M., \& García, P. (2015). A web survey analysis of subjective well-being. International Journal of Manpower.,36 (1), pp. 48-67

Atikbay, T., \& Öner, Y. (2020). Effects of human resources management practices and organizational justice perceptions on organizational cynicism: A research on municipalities in a developing country. Management Science Letters, 10(8), 1659-1670. 
Auer, P., \& Cazes, S. (2000). Resilience of the Long-Term Employment Relationship: Evidence from teh Industrialized Countries. International Labour Review., 139, 379.

Ayala, Y., Silla, J. M. P., Tordera, N., Lorente, L., \& Yeves, J. (2017). Job satisfaction and innovative performance in young spanish employees: Testing new patterns in the happyproductive worker thesis-A discriminant study. Journal of Happiness Studies, 18(5), 1377-1401.

Ayalew, R. (2019). Teachers Work Environment and Leavel of Job Satisfaction of Teachers in Government Secondary Schoolsn in Nefas-Silk Lafeto Sub-City of Addis Ababa (Doctoral dissertation, Addis Ababa University).

Aziri, B. (2011). The Job satisfaction: A literature review. Management Research \& Practice, 3(4), pp. 77-86.

Ballou, N. S. (2013). The effects of psychological contract breach on job outcomes. Master's Theses. 4327. DOI: https://doi.org/10.31979/etd.sqy9-ugdf

Bankins, S. (2015). A process perspective on psychological contract change: Making sense of, and repairing, psychological contract breach and violation through employee coping actions. Journal of Organizational Behavior, 36, 1071-1095.

Bashir, S., \& Nasir, M. (2013). Breach of psychological contract, organizational cynicism and union commitment: A study of hospitality industry in Pakistan. International Journal of Hospitality Management, 34, 61-65.

Bernerth, J. B., Armenakis, A. A., Feild, H. S., \& Walker, H. J. (2007). Justice, cynicism, and commitment: A study of important organizational change variables. Journal of Applied Behavioral Science, 43(3), 303-326.

Bhuain, S.N., \& Menguc, B. (2002). An extension and evaluation of job characteristics, organizational commitment, and job satisfaction in an expatriate, guest's worker, sales salting. Journal of Personal Selling and Sales Management, 22(1),1-11.

Bordia, P., Restubog, S. L. D., Bordia, S., \& Tang, R. L. (2010). Breach begets breach: Trickledown effects of psychological contract breach on customer service. Journal of management, 36(6), 1578-1607.

Brandes, P., Dharwadkar, R., \& Dean, J. W. (1999, May). Does organizational cynicism matter? Employee and supervisor perspectives on work outcomes. In Eastern Academy of Management Proceedings, 2, 150-153.

Brown, J., Taylor, M., McKenzie, P., \& Perkins, K. (2015). Investing in Workforce Literacy Pays: Building Employer Commitment to Workplace Language, Literacy and Numeracy Programs.

Chandra, V. (2012). Workelife balance: Eastern and western perspectives. International Journal of Human Resource Management, 23(5), $1040 \mathrm{e} 1056$.

Chou, H. Y., Hecker, R. O. B., \& Martin, A. (2012). Predicting nurses' well-being from job demands and resources: A cross-sectional study of emotional labour. Journal of Nursing Management, 20(4), 502-511.

Conway, N., Kiefer, T., Hartley, J., \& Briner, R. B. (2014). Doing more with less? Employee reactions to psychological contract breach via target similarity or spillover during public sector organizational change. British Journal of Management, 25(4), 737-754.

Dahiya, R., \& Rangnekar, S. (2020). Validation of satisfaction with life scale in the Indian manufacturing sector. Asia-Pacific Journal of Business Administration.

Danganan, J. B., Velasquez, Z. F., Guinto, K. M. P., \& Mac, J. G. (2019). Quality of worklife of pharmacists in the Philippines: a descriptive, correlational study. Journal of Asian Association of Schools of Pharmacy, 8, 72-82. 
DeConinck, J. B. (2009). The effect of leader-member exchange on turnover among retail buyers. Journal of Business Research, 62(11), 1081-1086.

Deng, H., Shapiro, J., \& Yang, Q. (2018). Beyond reciprocity: A conservation of resources view on the effects of psychological contract violation on third parties. Journal of applied psychology, 103(5), 561.

Erlinghagen, M. (2019). Employment and its institutional contexts. KZfSS Kölner Zeitschrift für Soziologie und Sozialpsychologie, 71(1), 221-246.

Gigliotti, R., Vardaman, J., Marshall, D. R., \& Gonzalez, K. (2019). The role of perceived organizational support in individual change readiness. Journal of Change Management, 19(2), 86-100.

Gkorezis, P., Georgiou, L., \& Theodorou, M. (2018). High-performance work practices and nurses' intention to leave: The mediating role of organizational cynicism and the moderating role of human resource management-related educational background. The International Journal of Human Resource Management, 29(3), 465-484.

Gong, Y., Wu, Y., Huang, P., Yan, X., \& Luo, Z. (2020). Psychological Empowerment and Work Engagement as Mediating Roles Between Trait Emotional Intelligence and Job Satisfaction. Frontiers in Psychology, 11.

Grama, B. (2017). Organizational cynicism: Its relationship with job satisfaction. Revista Economică, 69(1), 42-51.

Homburg, C. \& Stock, R. (2005) Exploring the conditions under which salesperson work satisfaction can lead to customer satisfaction, Psychology \& Marketing, 22(5), pp. 393420.

Hussami M (2008). A Study of nurses' job satisfaction: The relationship to organizational commitment, perceived organizational support, transactional leadership, transformational leadership, and level of education. European Journal of Science Research, 22(2): 286-295.

Ince, M., \& Turan, Ş. (2011). Organizational cynicism as a factor that affects the organizational change in the process of globalization and an application in Karaman's public institutions. European Journal of Economics, Finance and Administrative Sciences, 37(37), 104-121.

Jacobs, C. D., Kreutzer, K., \& Vaara, E. (2020). Political Dynamics in Organizational Identity Breach and Reconstruction: Findings from the Crisis in UNICEF Germany. Academy of Management Journal, (ja).

Judge T. A., Mueller J. D. (2012). General and specific measures in organizational behavior research: considerations, examples, and recommendations for researchers. Journal of Organizational Behavior, 33 161-174.

Karakaya, B. (2019). Resmi ve özel okullarda beden eğitimi öğretmenlerinde örgütsel sinizm ve tükenmişlik düzeyleri (Master's thesis, İstanbul Gelişim Üniversitesi Sağlık Bilimleri Enstitüsü).

Kuang, W. (2013). The effects of psychological contract breach on employee work behaviors in the airline industry: Employee cynicism as mediator. International Journal of Business and Social Science, 4(12), 304-312.

Kwok, S. Y., Cheng, L., \& Wong, D. F. (2015). Family emotional support, positive psychological capital and job satisfaction among Chinese white-collar workers. Journal of Happiness Studies, 16(3), 561-582. 
Lashari, A. A., Shah, I. A., Malkawy, S., \& Parveen, S. (2019). "Measuring the factors affecting Job Characteristics with Personal outcomes" (A Case Study of Khairpur Sugar Mill). Archives of Business Research, 7(11), 104-118.

Leung, A. S., Cheung, Y. H., \& Liu, X. (2011). The relations between life domain satisfaction and subjective well-being. Journal of Managerial Psychology, 26(2), 155-169.

Li, S., \& Chen, Y. (2018). The relationship between psychological contract breach and employees' counterproductive work behaviors: the mediating effect of organizational cynicism and work alienation. Frontiers in Psychology, 9, 1273.

Mardanov, I. T., Heischmidt, K., \& Henson, A. (2008). Leader-member exchange and job satisfaction bond and predicted employee turnover. Journal of Leadership \& Organizational Studies, 15(2), 159-175.

Marselou, P (2017). The effect of psychological contract breach on job satisfaction and burnout: The influence of conscientiousness and reneging or incongruent psychological contract breach. Master's Thesis Human Resource Studies

Mayorga, M. W. (2019). An Introspection Intervention for Perceived Inefficacy in Charitable Giving (Doctoral dissertation, University of Oregon).

Memduhoğlu, H. B., \& Altunova, N. (2020). Views of the classroom teachers working in resource rooms about support education activities. Elementary Education Online, 19(2), 991-1004.

Middermann, L. H., Kratzer, J., \& Perner, S. (2020). The Impact of Environmental Risk Exposure on the Determinants of Sustainable Entrepreneurship. Sustainability, 12(4), 1534.

Mousa, M., \& Abdelgaffar, H. A. (2017). Afloat in uncertainty and cynicism: An experience from egypt. Kuwait Chapter of the Arabian Journal of Business and Management Review, 6(10), 1-15.

Muhidin, S. A. (2019). Determinant Factors Of Teacher Performance And Students' Competency. JPBM (Jurnal Pendidikan Bisnis dan Manajemen), 5(1), 22-35.

Nair, P., \& Kamalanabhan, T. J. (2010). The impact of cynicism on ethical intentions of Indian managers: The moderating role of seniority. Journal of International Business Ethics, 3(1), 14.

Obodo, P. A., Okonkwo, E. A., \& Aboh, U. J. (2019). JOB CHARACTERISTICS AND JOB SATISFACTION AMONG POLICE OFFICERS IN ENUGU URBAN. Practicum Psychologia, 9(1).

Özler, D. E., \& Atalay, C. G. (2011). A research to determine the relationship between organizational cynicism and burnout levels of employees in health sector. Business and management review, 1(4), 26-38.

Peiró, J. M., Kozusznik, M. W., Molina, I., \& Tordera, N. (2019). The Happy-Productive Worker Model and Beyond: Patterns of Wellbeing and Performance at Work. International journal of environmental research and public health, 16(3), 479.

Pisani, J., Sapir, A., Véron, N., \& Wolff, G. B. (2012). What kind of European banking union? (No. 2012/12). Bruegel Policy Contribution.

Price, J. L. (2001). Reflections on the determinants of voluntary turnover. International Journal of manpower.

Putranta, M. P. (2020). The Attitudes toward Codes of Ethics: Do Cynicism and Religiosity Matters? Media Ekonomi dan Manajemen, 35(1), 128-136.

Rahim, A. (1982). Demographic variables in general job satisfaction in a hospital: A multivariate study. Perceptual and Motor Skills, 55(3), 711-719. 
Shiekh et al... The Relationship of Organizational

Rayton, B. A., \& Yalabik, Z. Y. (2014). Work engagement, psychological contract breach and job satisfaction. The International Journal of Human Resource Management, 25(17), 23822400.

Robinson, S. L., \& Morrison, E. (2000). The development of psychological contract breach and violation: A longitudinal study. Journal of organizational Behavior, 21(5), 525-546.

Rothman, S., \& Coetzer, E. P. (2002). The relationship between personality dimensions and job satisfaction. Management Dynamics: Journal of the Southern African Institute for Management Scientists, 11(1), 29-42.

Sempane, M., Rieger, H.S., Roodt, G. (2002), Job satisfaction in relation to organizational culture, SA Journal of Industrial Psychology, 28(2): 23-30. DOI: 10.4102/sajip.v28i2.49.

Sirovátka, T., Guzi, M., \& Saxonberg, S. (2019). Satisfaction with democracy and perceived performance of the welfare state in Europe. Journal of European Social Policy, 29(2), 241256.

Solinger, O. N., Hofmans, J., Bal, P. M., \& Jansen, P. G. (2016). Bouncing back from psychological contract breach: How commitment recovers over time. Journal of Organizational Behavior, 37(4), 494-514.

Spector, P. E. (1997). Job satisfaction: Application, assessment, causes, and consequences (Vol. 3). Sage publications.

Stanley, D. J., Meyer, J. P., \& Topolnytsky, L. (2005). Employee cynicism and resistance to organizational change. Journal of business and psychology, 19(4), 429-459.

Stewart, J. E. (1983). Hospital pharmacists' job satisfaction: a review of the data. Topics in hospital pharmacy management, 3(1), 1.

Thompson, J. A., \& Bunderson, J. S. (2003). Violations of principle: Ideological currency in the psychological contract. Academy of Management Review, 28(4), 571-586

Volpe, R. L., Mohammed, S., Hopkins, M., Shapiro, D., \& Dellasega, C. (2014). The negative impact of organizational cynicism on physicians and nurses. The health care manager, 33(4), 276.

Wen, C. T. Y., Muthuveloo, R., \& Ping, T. A. (2018). Factors influencing job satisfaction: A perspective of millennials in Malaysia multinational (MNC) companies. Global Business and Management Research, 10(1), 48-66.

Wiechers, H.E., Shapiro J.A.M., Lub X.D., Have, S. (2018). Triggering psychological contract breach. In Handbook of Research on the Psychological Contract at Work, ed. CL Cooper, Y Griep. Northampton, MA: Edward Elgar Publ.

Wong, W. J., Norzi, A. M., Chan, C. L., \& Jaafar, F. S. (2020). The effects of enhanced primary healthcare interventions on primary care providers' job satisfaction. BMC Health Services Research, 20(1), 1-12.

Yang, X., Ge, C., Hu, B., Chi, T., \& Wang, L. (2009). Relationship between quality of life and occupational stress among teachers. Public Health, 123(11), 750-755.

Yang, Y., \& Islam, D. M. T. (2020). Work-life Balance and Organizational Commitment: A Study of Field Level Administration in Bangladesh. International Journal of Public Administration, 1-11.

Yeşilyaprak, B., \& Boysan, M. (2015). Latent class analysis of job and life satisfaction among school counselors: A national survey. Journal of Happiness Studies, 16(1), 1-15. 